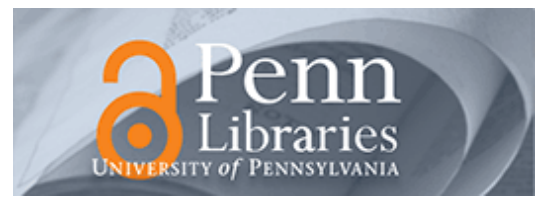

University of Pennsylvania

ScholarlyCommons

Accounting Papers

Wharton Faculty Research

$12-1999$

\title{
The Use of Equity Grants to Manage Optimal Equity Incentive Levels
}

John E. Core

Wayne R. Guay

University of Pennsylvania

Follow this and additional works at: https://repository.upenn.edu/accounting_papers

Part of the Accounting Commons, and the Business Administration, Management, and Operations Commons

\section{Recommended Citation}

Core, J. E., \& Guay, W. R. (1999). The Use of Equity Grants to Manage Optimal Equity Incentive Levels. Journal of Accounting and Economics, 28 (2), 151-184. http://dx.doi.org/10.1016/ S0165-4101(99)00019-1

This paper is posted at ScholarlyCommons. https://repository.upenn.edu/accounting_papers/108

For more information, please contact repository@pobox.upenn.edu. 


\title{
The Use of Equity Grants to Manage Optimal Equity Incentive Levels
}

\begin{abstract}
We predict and find that firms use annual grants of options and restricted stock to CEOs to manage the optimal level of equity incentives. We model optimal equity incentive levels for CEOs, and use the residuals from this model to measure deviations between CEOs' holdings of equity incentives and optimal levels. We find that grants of new incentives from options and restricted stock are negatively related to these deviations. Overall, our evidence suggests that firms set optimal equity incentive levels and grant new equity incentives in a manner that is consistent with economic theory.
\end{abstract}

\section{Keywords}

contracting, managerial compensation, managerial ownership, equity incentives, stock options

Disciplines

Accounting | Business | Business Administration, Management, and Operations 


\title{
The use of equity grants to manage optimal equity incentive levels
}

\author{
John Core ${ }^{\mathrm{E}}$, Wayne Guay \\ The Wharton School, University of Pennsylvania, 2400 Steinberg-Dietrich Hall, Philadelphia, \\ PA 19104-6365, USA
}

(Received October, 1998; final version received September 1999)

\begin{abstract}
We predict and find that firms use annual grants of options and restricted stock to CEOs to manage the optimal level of equity incentives. We model optimal equity incentive levels for CEOs, and use the residuals from this model to measure deviations between CEOs' holdings of equity incentives and optimal levels. We find that grants of new incentives from options and restricted stock are negatively related to these deviations. Overall, our evidence suggests that firms set optimal equity incentive levels and grant new equity incentives in a manner that is consistent with economic theory.

JEL Classification: G32; J33; J41; M4

Key words: Contracting; Managerial compensation; Managerial ownership; Equity incentives; Stock options

\footnotetext{
* Corresponding author. Tel: (215) 898-4821; fax:(215) 573-2054; e-mail: jcore@ wharton.upenn.edu

This paper was previously titled "The Stock and Flow of CEO Equity Incentives." We thank Ray Ball (the editor), Linda Bamber, Jennifer Gaver, Ken Gaver, Jarrad Harford, Ludger Hentschel, S.P. Kothari, Rick Lambert, David Larcker, Andy Leone, Amin Mawani, Wayne Mikkelson, Madhav Rajan, Cathy Schrand, Nathan Stuart, Richard Willis, an anonymous referee, and seminar participants at Duke University, Michigan State University, the University of Georgia, the University of Oregon, the University of Pennsylvania, and the University of Rochester for helpful comments. We thank Howard Yeh for research assistance. The financial support of the Wharton School is gratefully acknowledged.
} 


\section{Introduction}

Beginning with Jensen and Meckling (1976) and Demsetz and Lehn (1985), researchers have hypothesized that optimal equity ownership incentives vary with firm characteristics. Although empirical research supports these predictions for the level of equity incentives, there is mixed empirical evidence on whether firms' grants of equity incentives are consistent with economic theory of optimal contracting (e.g., Yermack, 1995; Ofek and Yermack, 1997). We reexamine firms' grants of equity incentives using more comprehensive measures of equity incentives, improved empirical methods, and more carefully-constructed hypotheses.

Overall, our evidence suggests that firms set optimal equity incentive levels and grant stock options and restricted stock in a manner that is consistent with economic theory. Following prior research on the determinants of managerial ownership (e.g., Demsetz and Lehn, 1985) and on the determinants of equity compensation (e.g., Smith and Watts, 1992), we develop a crosssectional model for the optimal level of CEO equity incentives. We find that the optimal portfolio of incentives from stock and options varies with hypothesized economic determinants such as firm size, growth opportunities, and proxies for monitoring costs. Over time, CEOs' holdings of equity incentives can become misaligned with optimal levels, either because the optimal levels shift or because of changes in the incentives provided by CEOs' stock and option portfolios. We use the residual from our regression model of CEOs' optimal level of equity incentives to measure the extent to which a CEO's incentives deviate from the optimal level. Consistent with firms using stock-based compensation effectively, we present evidence that firms actively manage grants of new equity incentives to CEOs in response to deviations from an optimal level of equity incentives. This result is robust to several alternative specifications of our 
models, as well as to controlling for reasons why firms use stock compensation as a substitute for cash compensation and to controlling for expected CEO trading behavior.

This study differs from previous work in two primary ways. First, our theory and empirical tests model separately the determinants of CEOs' portfolio holdings of equity incentives and new grants of equity incentives. This two-stage approach represents a departure from studies such as Yermack (1995), Bryan, Hwang, and Lilien (1998), and Janakiraman (1998). These studies use annual grants of stock options as a proxy for both new grants of equity incentives and the level of the CEO's incentive holdings. In contrast, we argue that the determinants of new equity grants to CEOs differ from the determinants of optimal equity ownership levels. Specifically, we hypothesize that the use of new incentive grants depends upon the deviation between optimal incentive levels and CEOs' existing incentive levels, firms' desire to pay compensation in stock and options, and the benefits of deferred compensation.

Second, we use more comprehensive measures of equity incentives than have been used in prior research. We measure a CEO's holdings of equity incentives as the total incentives provided by his portfolio of stock and options. In contrast, most research on the cross-sectional determinants of managers' equity incentives uses only managers' stockholdings (or beneficial ownership) as a proxy for equity incentives. ${ }^{\mathrm{W}} \mathrm{We}$ find that the explanatory power for our measure of total incentives is substantially greater than for an incentive measure that consists solely of CEOs' stockholdings. Further, our measure of incentives from options encompasses the CEO's entire portfolio of options. Due to data limitations, studies that incorporate option incentives often use the incentives from new option grants as a proxy for the CEO's portfolio of option

\footnotetext{
${ }^{1}$ Exceptions are Bizjak, Brickley, Coles (1993) and Palia (1998). Murphy (1985), Jensen and Murphy (1990), and Hall and Liebman (1998) have constructed measures of CEOs' total portfolio incentives, but focus on the magnitude of these incentives, not their determinants in equilibrium.
} 
incentives, as in Yermack (1995) and Palia (1998). ${ }^{\text {Finally, our proxy for newly granted equity }}$ incentives includes both options and restricted stock. Failure to capture all the components of CEOs' equity incentives results in measurement error that can either reduce the power of the researcher's tests or lead to spurious inferences.

The remainder of this paper is organized as follows. In Section 2, we define our measure of equity incentives, develop a model for the optimal level of incentives, and predict that deviations from this level will affect grants of equity incentives. We describe the data in Section 3, and present the results of our tests in Section 4. We provide sensitivity tests of our results in Section 5. In Section 6, we provide a summary and concluding remarks.

\section{Hypothesis development and empirical specification}

We hypothesize that there exists an optimal level of equity incentives for a firm, and that firms use grants of stock and options to adjust portfolio incentives to the optimal level. We predict that new grants of equity incentives are negatively associated with the degree to which the CEO's portfolio incentives exceed the optimal level.

Over time, managers' equity incentives become misaligned with the optimal incentive level. One reason is that firm characteristics and manager characteristics that drive optimal incentive levels change with time. Another reason is that managers periodically sell and purchase stock, and exercise options. Finally, the incentives provided by a given portfolio of stock and options change over time. For example, the incentives provided by an option portfolio vary with stock price, stock-return volatility, and the time remaining until the options expire.

In the following section, we define our measures of the incentives provided by options and stock. To test our joint hypothesis that firms increase or decrease their annual incentive

\footnotetext{
${ }^{2}$ The incentives provided by new grants of options are a noisy proxy for the incentives from the CEO's portfolio
} 
grants to maintain an optimal incentive level, we first develop a model in Section 2.2 for the optimal level of equity incentives held by a CEO at a point in time. We use the residuals from this model as an estimate of the deviation between the CEOs' existing incentives and the optimal level of incentives. We predict that these residuals are negatively related to new grants of equity incentives to CEOs in the following year. In Section 2.3 we define a model for grants of equity incentives that provides the basis for our joint hypothesis test.

\subsection{Definition of $C E O$ equity incentives}

We define equity incentives as the change in the dollar value of the CEO's stock and options for a $1 \%$ change in the stock price. It is straightforward to compute this measure of incentives for stockholdings, since stock value increases by $1 \%$ for each $1 \%$ increase in the stock price. Computation of the incentives provided by options is more complex because the percentage increase in the value of an option is less than the percentage increase in the stock price, and depends upon the parameters embedded in the option contract.

Consistent with prior research by Jensen and Murphy (1990), Yermack (1995), and Hall and Liebman (1998), we estimate the sensitivity of an option's value to the stock price as the partial derivative of option value with respect to price (the option "delta"). Like this prior research, we assume that the appropriate risk-neutral valuation for an executive stock option is given by the Black-Scholes (1973) model, as modified by Merton (1973) to account for dividend payouts. The delta for a typical, newly granted, long-term executive stock option is approximately 0.75 , which means that the option value increases by $\$ 0.75$ when the stock price increases by $\$ 1.00$. 国 To transform this option delta into the dollar change in the value of the

\footnotetext{
holdings of options, as the two variables have a correlation of roughly 0.50 (Core and Guay, 1999).

${ }^{3}$ Due to managers' risk-aversion and the non-transferability of employee stock options, managers are likely to exercise sooner than is assumed by the Black/Scholes/Merton model (see Huddart, 1994; Cuny and Jorion, 1995). Adjusting the Black/Scholes model to accommodate these differences is not straight-forward. It is important to note
} 
option for a $1 \%$ change in the stock price, we multiply the option delta by $1 \%$ of the firm's stock price.

We estimate the total incentives from the CEO's option portfolio as the sum of the deltas of each option held by the CEO multiplied by $1 \%$ of price, and the total incentives provided by an option grant as the sum of the deltas of each option granted multiplied by $1 \%$ of price. Details of this computation are provided in Appendix A.1. We measure a CEO's portfolio equity incentives by adding the total incentives from the CEO's option portfolio to $1 \%$ of the value of the CEO's holdings of stock and restricted stock. Similarly, we measure the incentives provided by a new grant of options and restricted stock by adding the total incentives from the option grant to $1 \%$ of the value of the grant of restricted stock.

In contrast to our measure of total CEO equity incentives as the dollar change in CEO wealth for a percentage change in firm value, most prior researchers have focused on the dollar change in CEO wealth for a dollar change in firm value (e.g., Demsetz and Lehn, 1985; Jensen and Murphy, 1990; Yermack, 1995). ${ }^{1}$ When computed for stockholdings only, the change in CEO wealth for a dollar change in firm value is proportional to the fraction of shares outstanding owned by the CEO. The dollar change measure can be converted to a percentage change measure by multiplying it by the market value of the firm. For example, Jensen and Murphy (1990) and later Yermack (1995) estimate the sensitivity of the CEO's holdings of stock and options to stock price with respect to a $\$ 1,000$ dollar change in the value of common stock. As such, our measure is equal to the Jensen and Murphy measure multiplied by the market value of the firm, and

\footnotetext{
that a manager's utility increases with stock price regardless of whether the manager expects to exercise early, and that, for most parameter values, the sensitivity of option value to stock price for a 5-year option is not substantially different from that of a 10-year option. For example, the per option sensitivity of an at-the-money 10-year option is 0.76 for a stock with volatility of 0.3 and dividend yield of $1 \%$ when the risk-free rate is $6 \%$. The per option sensitivity decreases to 0.72 if the maturity of the option is reduced to 5 years.

${ }^{4}$ A recent exception is Himmelberg, Hubbard, and Palia (1999), who examine both measures of managerial
} 
divided by $\$ 100,000$.

Although the two measures differ in how they are deflated, the important distinction between these measures is the differing underlying assumptions about what drives incentives. The Jensen-Murphy measure assumes that incentives increase with a manager's fractional ownership of the firm, whereas our measure assumes that incentives increase with a manager's dollar ownership of the firm.

Recent research discusses the relative advantages of these two measures of CEO incentives. Haubrich (1994) and Hall and Liebman (1998) argue that managerial risk-aversion and wealth constraints imply that managers can have powerful incentives with even small fractional shareholdings. Baker and Hall (1998) argue that how CEO actions are assumed to affect firm value determines which measure is more appropriate. For example, when CEO actions primarily affect firm dollar returns (such as perquisite consumption through the purchase of a corporate jet), the appropriate measure of CEO incentives is his percentage holding in the firm. In contrast, when CEO actions primarily affect firm percentage returns (such as the implementation of firm strategy), the appropriate measure of CEO incentives is his dollar holding in the firm (Baker and Hall, 1998, pp. 8-9).

We use the change in CEO wealth for a $1 \%$ change in firm value as the primary incentive measure in our reported results. Because Baker and Hall (1998) find that this incentive measure increases at a decreasing rate with firm size, and consistent with Himmelberg, Hubbard, and Palia (1999), we use the logarithmic transformation of this measure in our tests. In Section 5.4, we provide evidence that the inference with respect to our joint hypothesis is unchanged when we use the Jensen and Murphy (1990) fractional holdings measure of incentives. 


\subsection{Determinants of the level of CEOs' portfolio holdings of equity incentives}

To specify a model for CEOs' portfolio holdings of equity incentives, we draw upon two bodies of research. The first includes work by Demsetz and Lehn (1985), Jensen (1986), Palia (1998), and Himmelberg, Hubbard, and Palia (1999) on the determinants of managerial ownership. The second body of research, including work by Smith and Watts (1992), Gaver and Gaver (1993), and Yermack (1995), examines the determinants of stock-based compensation.

Demsetz and Lehn (1985) hypothesize that managerial equity ownership is related to firm size and monitoring difficulty. They argue that there is an optimal firm size and optimal level of managerial ownership given the firm's factor inputs and product markets. If the optimal firm size is large, the dollar cost of a fixed proportionate equity ownership is also correspondingly large. Thus, larger firms are hypothesized to exhibit a lower percentage ownership. Since we model equity incentives due to stock ownership as a function of managers' dollar ownership, we expect that the level of equity incentives will increase at a decreasing rate with firm size.

In addition, larger firms require more talented managers who are more highly compensated (Smith and Watts, 1992) and consequently are expected to be wealthier (Baker and Hall, 1998). Under the typical assumption that managers' utility functions exhibit declining absolute risk aversion (constant relative risk aversion), we expect that CEOs of larger firms will have higher equity incentives (Baker and Hall, 1998; Himmelberg, Hubbard, and Palia, 1999). Both Baker and Hall (1998) and Himmelberg, Hubbard, and Palia (1999) find that CEO portfolio incentives increase at a decreasing rate with firm size. Following Demsetz and Lehn (1985) and Baker and Hall (1998), we use the logarithm of the market value of equity as a proxy for firm size. 
Demsetz and Lehn hypothesize that firms operating in less predictable, or noisier, environments have higher monitoring costs. Because of these higher monitoring costs, Demsetz and Lehn argue that firms operating in noisier environments will exhibit a higher concentration of ownership, but that managerial risk aversion implies that ownership levels will increase at a decreasing rate with noise. Following Demsetz and Lehn, we use idiosyncratic risk as a proxy for noise that increases monitoring costs. $\mathrm{We}$ measure idiosyncratic risk as the standard deviation of the residual from a 36-month market model regression, and predict a positive association between this variable and the level of equity incentives. Because incentives are expected to increase at a decreasing rate with noise, we capture the expected concave relation between increases in noise and increases in incentives by using a logarithmic transformation of idiosyncratic risk.

Extending the results of Demsetz and Lehn (1985), subsequent researchers have identified and examined additional determinants of variation in optimal levels of managerial ownership. Smith and Watts (1992) hypothesize and find a positive relation between firms' growth opportunities and the degree to which firms use equity incentives to tie a manager's wealth to firm value. Similar to the intuition behind Demsetz and Lehn's (1985) predicted relation between noise and managerial incentives, Smith and Watts hypothesize that the prevalence of growth options makes it more difficult for shareholders or outside board members to determine the appropriateness of managers' actions. The use of equity-based compensation

\footnotetext{
${ }^{5}$ To proxy for noise, empirical researchers have used both total risk (e.g., Demsetz and Lehn, 1985; Palia, 1998) and idiosyncratic risk (Demsetz and Lehn, 1985; Himmelberg, Hubbard, and Palia, 1999). Since total return variance and idiosyncratic return variance are highly correlated, our empirical results are qualitatively the same with either measure (see also Demsetz and Lehn, 1985). To the extent that market risk can be filtered out of performance measures, idiosyncratic risk is the theoretically superior measure (Holmstrom, 1982).
} 
such as stock options or restricted stock, lowers monitoring costs by providing managers with incentives to maximize shareholder value. Gaver and Gaver (1993), Mehran (1995), Palia (1998), and Himmelberg, Hubbard, and Palia (1999) provide additional support for this hypothesis by documenting a positive association between proxies for growth opportunities and CEOs' equity incentives. Following Smith and Watts (1992), we use the book value of assets divided by the market value of assets as a proxy for growth opportunities, and expect that firms with higher growth opportunities will have lower book-to-market ratios.

Jensen (1986) argues that the combination of low growth opportunities and high free cash flow creates agency problems that can be mitigated with higher levels of equity incentives. Palia (1998) and Himmelberg, Hubbard, and Palia (1999) find a positive association between operating income (as a proxy for free cash flow) and managerial ownership. Thus, ceteris paribus, managerial ownership and free cash flow are expected to be positively related for firms with low growth opportunities. Following Lang, Stulz, and Walkling (1991), we measure the free cash flow problem as the three-year average of [(operating cash flow - common and preferred dividends) / total assets] if the firm has a book-to-market assets ratio greater than one (a proxy for low growth opportunities), and zero otherwise.

We predict a positive relation between CEO tenure and incentive levels. One intuition for this prediction is that, over time, uncertainty about a CEO's ability is resolved. As the risk borne by the CEO due to uncertainty about his ability is reduced, it is possible to impose more incentive risk on him, ceteris paribus (Gibbons and Murphy,1992; Milbourn, 1998). Further, as CEOs approach retirement, increased equity incentives can be used to counteract potential horizon problems (Dechow and Sloan, 1991). Finally, CEO tenure may serve as a proxy for CEO wealth (Guay, 1999). Palia (1998) finds an increasing relation between CEO experience and CEO equity 
incentives. We use the logarithm of managers' tenure as CEO as a proxy for experience and potential horizon problems.

Finally, we include 19 industry indicator variables in the specification to control for industry effects. Our annual model for the level of equity incentives held by the CEO is summarized as:

$\log (\text { Portfolio equity incentives })_{\mathrm{it}-1}=\beta_{0}+\beta_{1} \log (\text { market value of equity })_{\mathrm{it}-1}+$ $\beta_{2} \log (\text { Idiosyncratic risk })_{\mathrm{it}-1}+\beta_{3}$ Book-to-market $\mathrm{it}_{\mathrm{t}-1}+$ $\beta_{4} \log (\text { CEO tenure })_{\mathrm{it}-1}+\beta_{5}$ Free-cash-flow problem ${ }_{\mathrm{it}-1}+$ $\beta_{6}$ Industry controls $\mathrm{it}-1+\varepsilon_{\mathrm{it}-1}$

\subsection{Determinants of grants of CEO equity incentives}

We predict that firms use grants of stock-based compensation to adjust portfolio incentives to the optimal level. Since we assume that the optimal level of a CEO's portfolio equity incentives is approximated by equation (1), a negative (positive) residual, $\hat{\varepsilon}_{i t-1}$, from this model indicates that a CEO's incentives are below (above) the optimal level, and that a larger (smaller) incentive grant is expected in year $t$.

If firms use restricted stock and options as a substitute for cash compensation, it is important that we control for this use in our empirical tests. Although it is generally inefficient to compensate a risk-averse agent for past performance with risky claims (such as stock options or restricted stock), there are countervailing benefits to using stock-based compensation instead of cash. Reductions in contracting costs can offset the costs of compensating a risk-averse CEO with restricted stock and options. Specifically, firms may prefer to give stock-based compensation rather than cash because of cash and financing constraints (discussed below); because grants of options and restricted stock are not subject to the U.S. Internal Revenue Code Section 162(m) one million dollar limit on the tax-deductibility of fixed cash pay; because stock 
option grants are not expensed for financial reporting purposes (Matsunaga, 1995); or because stock options are a less visible means of increasing executive pay "in the face of public opposition to high pay levels" (Hall and Liebman, 1998). Indirect evidence suggests that firms pay part of the CEO's compensation with equity (e.g., Murphy, 1998), and there is empirical evidence that stock-based compensation is higher when firm performance is higher (e.g., Baber, Janakiraman, and Kang, 1996). The short vesting schedules on restricted stock and options (Kole, 1997) are consistent with firms wanting to make these grants available for compensatory purposes.

If firms deliver a portion of CEO total compensation through equity compensation, we predict that the average level of stock-based compensation will be higher when total compensation is higher. Following Smith and Watts (1992), we expect that the demand for a high quality $\mathrm{CEO}$, and thus the level of CEO compensation, is positively associated with growth opportunities and firm size, and that it reflects industry differences. Consistent with many other studies of CEO compensation levels (e.g., Smith and Watts, 1992), we measure firm size with $\log$ (sales), and growth opportunities with the book-to-market ratio. Further, we control for the potential association between total CEO compensation and firm performance (Baber, Janakiraman, and Kang, 1996) by including current year and prior year stock returns.

Because grants of stock options and restricted stock require no contemporaneous cash payout, firms with cash constraints are expected to use these forms of compensation as a substitute for cash pay (Yermack, 1995; Dechow, Hutton, and Sloan, 1996). Further, when future corporate tax rates are expected to be higher, the future tax deduction from deferred compensation becomes more favorable relative to the immediate tax deduction received from 
cash compensation. ${ }^{6}$ Therefore, ceteris paribus, the use of stock-based compensation is expected to be less costly for firms with low marginal tax rates. In support of these hypotheses, Yermack (1995), Matsunaga (1995), Dechow, Hutton, and Sloan (1996), and Bryan, Hwang, and Lilien (1998) find that the use of stock options is greater when firms have lower free cash flow and higher net operating loss carry-forwards. We measure the degree of cash flow shortfall as the three-year average of [(common and preferred dividends + cash flow used in investing activities cash flow from operations)/total assets]. As a proxy for firms' marginal tax rate, we use an indicator variable equal to one if the firm has net operating loss carry-forwards in any of the previous three years, and zero otherwise.

Another potential reason for why firms substitute stock option compensation for cash compensation is that cash compensation is expensed whereas the value of stock option grants is only disclosed in the footnotes to the financial statements. Thus, we expect that firms that are constrained with respect to earnings will grant more stock options, ceteris paribus. As a proxy for earnings constraints, we follow Dechow, Hutton, and Sloan (1996), and use the extent to which a lack of retained earnings constrains the firm's ability to pay dividends and make stock repurchases. We categorize a firm as dividend constrained if [(retained earnings at year-end + cash dividends and stock repurchases during the year)/the prior year's cash dividends and stock repurchases], is less than two in any of the previous three years. If the denominator is zero for all three years, we also categorize the firm as dividend constrained. The lack of dividend payments or stock repurchases is consistent with the firm being either earnings constrained or cash constrained.

\footnotetext{
${ }^{6}$ From the employee's perspective, deferred compensation such as restricted stock and options always provides higher after-tax returns (before adjusting for risk) than a cash payment of equal value because taxes on the return are deferred (Smith and Watts, 1982).
} 
The foregoing arguments suggest a model for grants of equity incentives that includes the incentive residual calculated using equation (1) and control variables for firms' use of stock compensation in lieu of cash compensation. We measure grant size as the logarithm of the equity incentives provided by the grant plus one. ${ }^{\square}$ Our model for new grants of equity incentives to the CEO is:

$$
\begin{aligned}
\log (\text { New incentive grant }+1)_{\mathrm{it}}= & \beta_{0}+\beta_{1} \text { Incentive residual }_{\mathrm{it}-1}+\beta_{2} \log \left(\text { sales }_{\mathrm{it}-1}+\right. \\
& \beta_{3} \text { Book-to-market }_{\mathrm{it}-1}+\beta_{4} \text { Net operating loss }_{\mathrm{it}-1}+ \\
& \beta_{5} \text { Cash flow shortfall }_{\mathrm{it}-1}+\beta_{6} \text { Dividend constraint }_{\mathrm{it}-1}+ \\
& \beta_{7} \text { Industry controls }_{\mathrm{it}-1}+\beta_{8} \text { Stock return }_{\mathrm{it}}+ \\
& \beta_{9} \text { Stock return }_{\mathrm{it}-1}+\mathrm{u}_{\mathrm{it}}
\end{aligned}
$$

Note that our main hypothesis is unaffected by whether or not firms also use equity grants as compensation. Our prediction is that firms require CEOs to maintain the optimal level of incentives, and that firms vary their grants to manage this optimum. If other frictions lead firms to grant additional stock and options as compensation, then firms will allow CEOs to exercise and sell stock and options so long as the aggregate amount of these sales are roughly equal to the proportion of the stock and options that have been granted as compensation. In Section 4.2, we show that the negative relation between the CEO's deviation from the optimal incentive level and new grants of incentives holds regardless of whether we control for the potential for firms to use stock compensation in lieu of cash. If the CEO receives stock and options as compensation, and if his trading behavior is such that he does not continuously rebalance his portfolio gains to recognize this compensation, the $\mathrm{CEO}$ can be above (below) the optimal level because his grants of equity compensation are greater than (less than) his sales of equity compensation. Such trading

\footnotetext{
${ }^{7}$ We model $\log ($ New incentive grant +1$)$ as a linear function of the residual, where the residual is equal to $\log ($ actual incentives/optimal incentives). This model is equivalent to modeling a correction to a percentage deviation, i.e., the new incentive grant is equal to $\alpha(\text { actual/optimal })^{\beta}-1$.
} 
behavior by the CEO would cause measurement error in our estimate of the optimal level of CEO incentives. In sensitivity analysis discussed in Section 5.3, we show that our inferences are unaffected if we control for the CEO's expected trading behavior.

\section{Sample and variable measurement}

In this section, we describe our sample selection process and the data we use to test our hypotheses. Our data come from three sources. We obtain data on CEO option and stock holdings and option and restricted stock grants from Standard and Poor's Execucomp database. CRSP data are used to generate measures of stock-return volatility and treasury bond yields. We use Compustat as the source for firms' financial data and industry classifications.

\subsection{Sample selection}

We obtain a sample of CEOs from the Execucomp database. Restricting our attention to non-financial firms, we begin with an initial sample of 7,121 CEO-year observations from December, 1992 through December, 1997. B We eliminate 391 and 287 observations due to missing CRSP and Compustat data, respectively, and 240 observations missing CEO option portfolio data. The final sample consists of 6,214 CEO-year observations from 1992 to 1997 . We test our hypotheses in two stages. In the first stage, we use 5,352 CEO-year observations from 1992 to 1996 to estimate the optimal level of CEO incentives. In the second stage, we use the 4,431 CEO-years from 1993 through 1997 where data are available on the CEOs' equity incentives in the prior year to examine the relation beginning-of-the-year deviations from optimal incentive levels and incentive grants during the year.

\subsection{Variable measurement}

\footnotetext{
${ }^{8}$ We begin the sample in December 1992 because consistent disclosure of option portfolios began at this time. We use the CEO in office at the end of the fiscal year. In the 112 cases in which a firm has more than one individual with the title of CEO, we drop the individual with the lower cash compensation in order to concentrate our tests on the
} 
As discussed above in Section 2.1, we define equity incentives as the sensitivity of stock and option value to a $1 \%$ change in stock price. To estimate models (1) and (2), we require measures of portfolio equity incentives at the end of year $t-1$ and new equity incentives granted during year $t$, respectively. New equity incentives granted during year $t$ are equal to the sum of the incentives provided by grants of restricted stock and the incentives provided by grants of options. To measure the incentives from option grants, we estimate the sensitivity of the BlackScholes value of the grant to a $1 \%$ change in the grant date stock price. ${ }^{\text {The }}$ six inputs to the Black/Scholes model (stock price, exercise price, time-to-maturity, expected stock-return volatility, expected dividend yield, and the risk-free rate) are readily accessible for CEOs' newly granted options. The quantity of options in the new grant, the grant-date stock price, the exercise price, and time-to-maturity are disclosed in the firm's annual proxy statement for the top five executives and are available from the Execucomp database. We measure the expected stockreturn volatility as the standard deviation of daily stock returns over the 120 trading days preceding the end of the fiscal year in which the grant was made. Expected dividend yield is estimated as cash dividends paid in the fiscal year the grant is made divided by year-end stock price. We use the treasury-bond yield corresponding to the option's remaining time-to-maturity to estimate the risk-free rate. We measure new incentives from restricted stock grants as the value of the stock grant multiplied by $1 \%$.

more important decision-maker.

${ }^{9}$ Since the incentive effects of new option grants can change between the grant date and the fiscal year end, an argument can be made that the incentive effects of new option grants should be measured using the year-end stock price. However, using the year-end stock price generates a mechanical relation between the incentive effects of the grant and current year firm performance (current year performance is an explanatory variable in our equation (2)). We report results using grant date stock price to avoid inducing this mechanical relation. However, with the exception of a more positive coefficient on current year stock return, the estimation of equation (2) is not sensitive to alternatively using the year-end stock price to estimate new grant incentives. 
Estimating total portfolio incentives from stock and options at the end of a given year $t-1$ is more complicated. Although the incentives provided by portfolio holdings of stock are easily estimated by multiplying year-end stock value by $1 \%$, full disclosure of the characteristics of executives' portfolio of options is beyond the scope of existing proxy reporting requirements. To avoid the cost and difficulty of collecting option data from multiple proxy statements, we use the methods developed by Core and Guay (1999) to estimate option portfolio incentives. This method has the convenient feature of requiring information from only the most recent proxy statement. To summarize their procedure, the incentives from newly granted options in year $t-1$ are estimated directly as described above using the stock price at the end of year $t-1$, and the incentives from previously granted options at the end of year $t-1$ are measured using estimates of average exercise price and average time-to-maturity. The details of this method are summarized in Appendix A.2. Core and Guay (1999) show that this method yields estimates of option portfolio sensitivities that are effectively unbiased and $99 \%$ correlated with the measures that would be obtained if the parameters of a CEO's option portfolio were known.

\section{Results}

\subsection{The level of CEOs' portfolios of equity incentives}

Table 1 presents descriptive statistics for portfolio equity incentives and their hypothesized determinants. The median change in CEO wealth for a $1 \%$ change in stock price is $\$ 117,000$, and this variable is substantially skewed (mean $=\$ 558,000)$. As discussed above, we use the logarithmic transformation of this measure in our tests. $\log$ (portfolio equity incentives) is much less skewed, with a mean of 11.68 and median of 11.67. To mitigate the influence of outliers, the upper and lower-most percentiles for each explanatory variable are set equal to the values at the $1^{\text {st }}$ and $99^{\text {th }}$ percentiles in each year, respectively. We report correlations between 
the explanatory variables in Panel B. With the exception of the large negative correlation between $\log (\mathrm{MV}$ equity) and $\log ($ idiosyncratic risk), all of the correlations are below 0.3 in magnitude.

The results in Table 2 indicate that the levels of CEO equity incentives are well-explained by the theory outlined in Section 2.2. We first present the results of an ordinary least squares estimation of equation (1) with 19 indicator variables to control for industry effects. The adjusted R-squared is $47.8 \%$, indicating that the model explains a substantial proportion of the crosssectional variation in equity incentives. Although the residuals we use in the second-stage tests are based on individual annual regressions, for parsimony, we present in Table 2 the results of a regression pooled over the five sample years from 1992 to 1996 with year indicator variables. With the exception of free-cash-flow problem, the coefficients on all of the explanatory variables are statistically significant and of the predicted sign. The positive coefficients on $\log (\mathrm{MV}$ equity) and $\log ($ idiosyncratic risk) are significantly less than one, indicating that CEO incentives increase at a decreasing rate with firm size and noise in the operating environment, as predicted by Demsetz and Lehn (1985). The positive associations between portfolio equity incentives and growth opportunities and CEO tenure are consistent with the findings of Smith and Watts (1992) and Palia (1998).

Much prior work on equity incentive levels focuses solely on stock ownership. To compare our results with this literature, we re-estimate equation (1) after excluding stock option

\footnotetext{
${ }^{10}$ The standard errors in the pooled regression in Table 2 will be overstated if there is serial correlation or crosssectional dependence in the residual. However, the inferences from the coefficients obtained from each of the annual cross-sectional regressions are the same as those reported in Table 2, indicating that our pooled regression results for equation (1) are not affected by serial correlation. Further, a Fama-MacBeth regression procedure yields inferences that are identical to the pooled results, indicating that the inference from equation (1) is not affected by crosssectional dependence.
} 
incentives from the dependent variable. The inference from the "Stock incentives only" regression is consistent with the results in Column 1. However, the adjusted R-squared value of $28.7 \%$ is substantially lower than in the specification that includes stock options. This lower explanatory power suggests that the sensitivity of CEO stockholdings to stock price is a less precise measure of $\mathrm{CEO}$ equity incentives than our measure that combines the incentive effects of stock and options.

\subsection{Grants of CEO equity incentives}

We use the residuals from individual annual estimations of equation (1) to estimate the extent to which a CEO's equity incentives deviate from the optimal level, and predict a negative relation between residuals estimated at the end of year $t-1$ and the equity incentives provided by new grants of stock options and restricted stock in the following year $t$. In addition, our regressions control for the relation between equity grants and: (1) the determinants of the level of CEOs' total compensation; and (2) the determinants of the use of deferred compensation.

Note that the specification of equation (2) relates incentive grants during year $t$ to the incentive residual at year-end $t-1$. By measuring the incentive residual at year-end $t-1$, we assume that firms measure the optimal level of incentives as of the end of a fiscal year and use this information to vary grant size in the following year. If firms adjust incentives continuously throughout the year, actual and optimal incentive levels will be identical and no association is expected between incentive grants during year $t$ and the incentive residual at year-end $t-1$. However, information gathering and processing costs prevent firms from continuously correcting deviations from optimal incentive levels. For example, estimating a CEO's optimal incentive level requires comparison compensation data from other CEOs at similar firms. This data is made publicly available only once each year when the proxy statement is disclosed. Moreover, it 
is costly for the firm and its compensation committee to gather and analyze this information, and it would be very costly to correct deviations on even a monthly basis. As a result, we expect that adjustments to incentive levels are made relatively infrequently, and that the annual adjustment window we examine is reasonable. In support of this view, we find that firms make more than one equity grant to their CEO in less than $10 \%$ of the fiscal years we examine.

If firms make grants at the beginning or middle of the year, the incentive residual at yearend $t-1$ is expected to be a relatively timely estimate of the deviation from optimal incentive levels. To the extent that firms make grants late in the year, it is possible that our estimate of the deviation from the optimal level will be stale (either because firm characteristics or the CEO's incentives have changed during the year), and therefore measure the deviation from optimal incentives with error. This error will reduce our ability to find a significant association between the residual and grant size.

If we have mis-measured the dependent variable in equation (1) or omitted any relevant independent variables, we could induce a spurious relation between the year $t-1$ incentive residual and the year $t$ grant. By concentrating on equity incentives, we measure total incentives with error because we do not consider implicit incentives (for example, the threat of termination and other implicit incentives discussed by Kole, 1997) and explicit incentives provided by cash compensation plans. As long as the use of these other incentives is ceteris paribus similar across firms, this omission introduces unsystematic error that reduces the power of our tests. However, if firms use other implicit or explicit incentives as a substitute for equity incentives,

\footnotetext{
${ }^{11}$ Measuring optimal incentive levels at the end of year $t$ would introduce information into the incentive residual that was not predetermined at the time of the grant (unless the grant was made exactly at the end of year $t$ ). In this case, we could induce a mechanical correlation between the incentive residual and the grant.

${ }^{12}$ One reason we focus on equity incentives is that they can be measured much more reliably than these other incentives, especially implicit incentives, which are extremely difficult to measure.
} 
and there is predictable variation in this use not captured by the independent variables in equation (1), then the measurement error in our dependent variable is systematic. In this case, the residual we use in the second-stage estimation will also contain systematic measurement error, which could induce spurious evidence either in favor of or against our hypothesis.

Although it is not possible to eliminate the potential for omitted variables bias, we are careful to include in equation (1) the variables suggested by prior research as the economic determinants of equity incentive levels. Moreover, our estimation results of equation (1) are consistent with economic theory and the findings of prior research. Finally, as discussed in Section 5.1, our results in estimating equation (2) are robust to several alternative specifications of equation (1), including a firm-effects estimation. The firm-effects specification controls for systematic measurement error in the dependent variable and omitted firm-specific characteristics that are constant through time (such as firm-specific differences in compensation policies and differences in monitoring technology).

Table 3 presents descriptive statistics on new grants of equity incentives and the incentive residuals, as well as a correlation matrix of the explanatory variables. In $74 \%$ of the 4,431 CEOyear observations, new equity incentives are granted. Due to CEO turnover, the number of observations used to examine the determinants of new incentive grants is about $20 \%$ smaller than the number used in the incentive levels model. The median incentive effect of a new grant of

\footnotetext{
${ }^{13}$ As an example of spurious evidence in favor of our hypothesis, consider a firm that consistently provides incentives in year $t-1$ by making a promise of a restricted stock grant in year $t$. For this firm we would understate the dependent variable in equation (1) at year-end $t-1$ and overstate the grant in year $t$. As a result, there would be a spurious negative correlation between the residual and the grant. As an example of spurious evidence against our hypothesis, consider a firm that provides "equity" incentives with cash long-term incentive plans that have the same payout structure of a stock option. For this firm, we would consistently understate the dependent variable in equation (1) at year-end $t-1$ and also understate the incentive grant during year $t$. As a result, there would be a spurious positive correlation between the residual and the grant.
} 
stock-based compensation is $\$ 12,251$. That is, the value of the median grant changes by $\$ 12,251$ for a $1 \%$ change in stock price.

By construction, the full sample of incentive residuals from estimating equation (1) has a mean of zero. Due to the loss of observations from CEO turnover as described above, the means of the residuals reported in Table 3 are not precisely zero, but are not significantly different from zero. The incentive residual is uncorrelated with the explanatory variables we use to estimate equation (2), with the exception of a small positive correlation with the dividend constraint variable.

We assume that the firm simultaneously chooses whether to make a grant of equity incentives, and the magnitude of the incentive grant conditional on making a grant. Following Heckman (1979), we model these two decisions as a simultaneous system, consisting of a probit model for the option grant decision and a linear regression model for the grant size decision (Appendix B describes our application of the Heckman model in greater detail):

$$
O^{*}=x_{1} \beta_{1}+\varepsilon_{1}
$$

$\log ($ New incentive grant +1$)=x_{2} \beta_{2}+\varepsilon_{2}$, if a grant is made and 0 otherwise

A firm makes a grant when the latent variable $O^{*}$ measuring the net benefits of a grant is greater than zero in equation (4). Contingent on having decided to make a grant, which occurs with probability less than one, we assume that the firm determines the size of the grant based on the model shown in equation (5). In this model, full data on the independent variables are observed, but data on the equity incentives are observed only when a grant is made.

When $x_{1}=x_{2}$ and $\beta_{1}$ is restricted to equal $\beta_{2}$ in the Heckman model, the Tobit model results. Consistent with the literature on stock option incentives, we first report the results of Tobit models. The principal advantage of the Tobit model is that it combines equations (4) and 
(5) into a single regression that allows for a compact presentation and interpretation of our results. We relax the restriction that $\beta_{1}=\beta_{2}$ below.

The Tobit results reported in Table 4 indicate that the incentive residuals, or deviations from optimal incentive levels, are an important determinant of grants of equity incentives. As with the specifications for the level of portfolio equity incentives, the incentive grant results are based on a pooled regression model with year indicator variables. ${ }^{1}$ The specification in Column 1 of Table 4 includes only the incentive residual. Consistent with our hypothesis that grant levels reflect an adjustment of CEOs' incentives toward their optimal level, we observe a significantly negative coefficient on the incentive residual. The -0.47 marginal effect of the incentive residual indicates that a CEO whose incentives are $10 \%$ below average receives a grant that is approximately $5 \%$ higher than a CEO with an optimal level of incentives. The magnitude of this marginal effect, in conjunction with the means of the dependent and independent variables, indicates that firms use equity grants to make a partial, but not full, adjustment to correct the deviation from the optimal incentive level.

Note that an implicit assumption underlying our hypothesis is that firms are able to increase CEOs' portfolio levels of incentives through grants of equity incentives. Ofek and Yermack (1997) find that executives sell 0.16 shares of stock for each option they are granted. They interpret this result as evidence that executives unwind the incentive effects of new grants. However, this interpretation assumes that one newly granted option provides roughly the same equity incentives as 0.16 shares of stock. In our sample, we estimate that a newly granted option provides equity incentives that are equivalent to approximately 0.75 shares of stock, on average. We confirm the Ofek and Yermack (1997) result that the number of common shares owned by an 
executive in our sample decreases slightly following a new grant. However, we find that, on average, CEOs sell only $20 \%$ of newly-granted incentives (not tabulated). Thus, the total incentives provided by a CEO's equity portfolio increase substantially in the year a grant is made.

The results reported in Column 2 of Table 4 reveal that the inclusion of variables that control for firms' use of equity compensation as an alternative to cash compensation has little effect on the magnitude and significance level of the incentive residual. Consistent with firms choosing to provide a portion of total compensation in the form of equity, likelihood ratio tests reject the exclusion of the 7 economic determinants and 19 industry indicator variables that control for the use of stock compensation as a substitute for cash compensation. Our findings indicate that equity compensation is significantly higher for larger firms and for firms with greater growth opportunities, consistent with the hypotheses of Smith and Watts (1992). The significantly positive coefficients on cash flow shortfall and dividend constraints are consistent with firms using equity compensation when cash is constrained and stock options when retained earnings are constrained.

In addition, grants of incentives exhibit a positive relation with firm performance, as evidenced by the significantly positive coefficient on current period stock return. However, because the stock return is measured over year $t$, its relation to incentive grants is potentially spurious. Since the stock return is correlated with changes in $\log$ (market value) and book-tomarket from year $t-1$ to year $t$, it could capture changes in the optimal incentive level during the year that the grant is made. In addition, our measure of new incentives granted during year $t$ varies with the grant date stock price, which is positively correlated with stock return during year $t$. For these reasons, we exercise caution in interpreting the positive coefficient on the year $t$ stock

\footnotetext{
${ }^{14}$ Specification checks described in Section 5.2 indicate that our inferences are not affected by potential cross-
} 
return as evidence that higher performance is rewarded with larger incentive grants. Our inference on the remaining variables is unchanged if we exclude the stock return variables from our estimation of equation (2).

As indicated above, the Tobit model restricts the coefficients on the explanatory variables to be the same in both the grant decision probit specification and the grant level OLS specification. In Table 5, we present a Heckman two-stage estimation of equation (2) that examines the determinants of the choice to grant stock-based compensation separately from the choice of grant size. As in the Tobit regressions, we report results for the pooled sample over the years 1993 to 1997, with year indicator variables. The first column reports a maximum likelihood estimation of a probit model for the determinants of a grant. In $26 \%$ of the firm-year observations, no grant is made. For the firm-year observations when a grant is made, the second column presents an OLS estimation with $\log (\mathrm{New}$ incentive grant +1$)$ as the dependent variable. The t-statistics presented are based on Heckman (1979) standard errors.

The probit model for the grant decision has significant explanatory power (p-value < 0.001), but a low pseudo R-squared of 5.9\%. Ofek and Yermack (1997) also report a low pseudo R-squared using a similar sample and dependent variable, but different explanatory variables. We find that the primary determinants of the decision to make a grant are the incentive residual and firm size. In addition, firms with better contemporaneous stock price performance are more likely to make grants. The coefficient on the incentive residual is negative and significant. The -0.16 coefficient indicates that the probability of a grant increases by $0.5 \%$ for a CEO whose incentives are $10 \%$ below average. The significantly positive coefficient on firm size is consistent with the probit results in Ofek and Yermack (1997).

sectional dependence and serial correlation in our pooled time-series cross-sectional regression models. 
The second-stage OLS regression examines the determinants of equity grant size, conditional on a grant being made. The explanatory power of this model is substantial, with an adjusted R-squared of $35.5 \%$. The coefficient on the incentive residual is negative, but insignificant. Thus, the additional insight of the Heckman model over the Tobit model is that the incentive residual appears to influence the expected magnitude of equity grants through the probability of a new grant, but not through an association with the grant size. The remaining explanatory variables -- book-to-market, $\log ($ sales), free cash flow, dividend constraint, and stock return -- have the expected signs and are significant.

In the last column of Table 5, we report the Heckman marginal effects computed at the means of the variables. The marginal effects combine the probit and OLS results into a measure of the overall association between the size of incentive grants and the explanatory variables. The Heckman and Tobit marginal effects have the same sign for each variable, indicating that the overall inference from the two models is identical. The -0.33 marginal effect of the incentive residual in the Heckman model is smaller than the effect shown for the Tobit model in Table 4, and indicates that a CEO whose incentives are $10 \%$ below average receives a grant that is approximately $3 \%$ higher than a CEO with an optimal level of incentives.

\section{Sensitivity analyses}

Consistent with our hypothesis, the results in Section 4 indicate that incentive grants are negatively related to deviations from the optimal level of equity incentives. To ensure the robustness of our results, we perform several sensitivity checks. As we report below, none of these tests yields different inferences from those reported above.

\subsection{Alternative specifications of equations (1) and (2)}


We perform a number of sensitivity tests to ensure that outliers are not driving our results. All results are robust to removing or winsorizing the CEOs with the largest and smallest $1 \%$ (or $5 \%$ ) of equity incentives in each year. All of the results are also robust to removing or winsorizing the CEOs with the largest and smallest $1 \%$ (or 5\%) of incentive residuals in each year. Finally, the inferences are unaffected by deleting CEOs that receive no incentive grants over the sample period, confirming that the results are not driven by CEOs to whom no incentive grants are given.

Our results in estimating equation (2) are robust to a number of different specifications of the first-stage model, equation (1). We obtain qualitatively the same results if: (1) we use the total variance of stock returns instead of idiosyncratic risk; (2) we proxy for the concave relation between monitoring difficulty and incentive levels with idiosyncratic risk and idiosyncratic risk squared instead of the $\log ($ idiosyncratic risk); or (3) we use $\log$ (sales) as a proxy for firm size instead of $\log (\mathrm{MV}$ equity).

The estimation of equation (1) reported in Table 2 assumes that the economic determinants and industry differences are sufficient to explain optimal incentive levels, and that any remaining firm-specific variation reflects a deviation from the firm's optimal incentive level. Palia (1998) and Himmelberg, Hubbard, and Palia (1999) argue that there may be firm-specific differences in monitoring technology not captured by the economic determinants and industry differences, and that these differences influence optimal incentive levels. Following their approach, we capture these firm-specific effects with a firm-effects estimation of equation (1) that replaces the industry indicators with an indicator for each firm. For each grant year $t$, we obtain year $t$ - 1 incentive residuals by estimating a pooled, time-series regression using data from 
all years up to and including year $t-1.5$ In addition to the firm indicator variables, we again include year indicator variables.

The firm-effects results presented in Column 1 of Table 6 are consistent with the equation (1) results from the industry-effects specification in Table 2. The equation (1) specification presented includes data from 1992 to 1996 . We use this specification to estimate firm-effects incentive residuals for 1996, which are used as an explanatory variable for the 1997 grant. The results from specifications that generate residuals for 1993, 1994, and 1995 are similar, but are not tabulated. $\log (\mathrm{MV}$ equity), book-to-market, and $\log (\mathrm{CEO}$ tenure) obtain significant coefficients with the predicted signs. Similar to the findings of Palia (1998), $\log ($ idiosyncratic risk) is insignificant, possibly because this measure has little annual variation due to the overlap in the three-year periods over which the measure is computed. The differences in coefficient magnitudes between the industry-effects and firm-effects models suggest that the firm-effects model is controlling for unobserved firm characteristics that are correlated with the observed characteristics (Himmelberg, Hubbard, and Palia, 1999).

The results from using the firm-effects residual as an explanatory variable in equation (2) are reported in Column 2 of Table 6. Because we require at least three CEO-year observations for each firm to estimate the fixed effects procedure (two observations for equation (1) and one future year for equation (2)), the sample is reduced to 3,237 CEO-year observations. The qualitative inference from this estimation is consistent with the results reported in Table 4. In particular, the coefficient on the incentive residual has the predicted negative sign and is significant.

\footnotetext{
${ }^{15}$ We exclude data from the grant year and all future years to avoid inducing a mechanical negative relation between the incentive residual and the magnitude of the new equity grant. In the absence of this procedure, a mechanical relation could result because the firm effects estimation forces the time-series mean residual for each firm to be zero.
} 


\subsection{Alternative standard errors}

Positive correlation in the regression error terms across firms, or within firms, would understate the standard errors of the coefficients in the pooled time-series cross-section regression, and thereby overstate the t-statistics (Smith and Watts, 1992). To address the potential cross-sectional dependence in the error terms, we use Fama-MacBeth (1973) regression procedures for the models in Tables 4 and 5 and the Tobit model in Table 6. Specifically, we estimate annual cross-sectional regressions and assess the significance of the time-series mean coefficient using the standard error of the annual coefficients. The signs of the estimated coefficients and inferences are unaffected by this procedure. In particular, the incentive residual remains significantly negative in both the Tobit and probit models, with substantial negative marginal effects in both models.

To address the potential time-series dependence in the error terms within firms, we randomly select one observation per firm and re-estimate the models in Tables 4 and 5 . The random sample contains 1,255 observations for which incentive grants are made in $73 \%$ of the firm-years. The signs and significance levels of all estimated coefficients are unaffected by this procedure. The sign and significance level of the estimated coefficient on the incentive residual is unaffected when we randomly select one observation per firm and re-estimate the Tobit model in Table 6.

\subsection{Controls for CEO trading behavior}

Janakiraman (1998) finds evidence consistent with the hypothesis that firms grant more options when they expect CEOs to reduce their incentive levels through option exercises. We measure the yearly change in CEOs' incentives due to trading activities as the logarithm of the percentage increase in CEO portfolio incentives from trading during the year: 
$\log [($ CEO equity incentives at end of year $t) /$

(CEO equity incentives at beginning of year $t$ valued at end of year $t$

+ grants of equity incentives during year $t$ valued at end of year $t)]$.

For a CEO who maintains a passive strategy with respect to equity incentives (i.e., the CEO retains all new grants, continues to hold all options and stock held at the beginning of the year, and makes no stock purchases), this measure has a value of 0 . Positive (negative) values of the measure indicate that the CEO's trading activities during the year increased (decreased) his incentives. We use this incentive change measure in year $t-1$ as a proxy for the firm's forecast of the CEO's trading activities in year $t$. If a CEO is risk-averse and poorly diversified with respect to his firm-specific wealth, sales of equity should be higher when the level of the CEO's equity incentives is above the optimal level. In addition, it is our hypothesis that a firm is more likely to permit its CEO to realize compensation when his incentives are above the optimal level. In support of this hypothesis, we find that CEOs with incentives above the optimal level sell higher proportions of their holdings than CEOs with incentives below the optimal level.

To determine whether this association between trading behavior and incentive levels influences our findings, we re-estimate the model (2) regressions in Tables 4 and 5 with the measure of expected CEO trading activities included as an additional regressor. Consistent with the findings of Janakiraman (1998), we find that incentive grants in year $t$ are larger when the

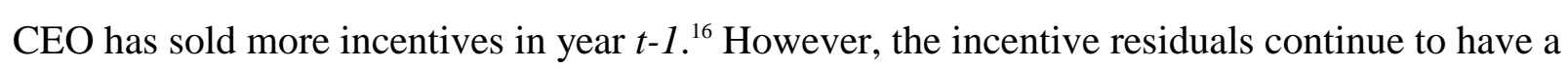
significantly negative association with the magnitude of incentive grants.

\subsection{Comparison using the Jensen-Murphy (1990) measure of CEO incentives}

\footnotetext{
${ }^{16}$ Note that because the sales of incentives by the CEO are readily observable, neither Janakiraman's (1998) findings nor our findings imply that the CEO uses trading activities to manipulate the board into granting more incentives. Rather, we infer from these results that the board wishes to replenish the CEO's incentives after he has realized compensation.
} 
To ensure that our inferences are unaffected by our choice of incentive measure, we reestimate equations (1) and (2) using the Jensen-Murphy (JM, 1990) measure of portfolio incentives defined in Section 2.1, and report the results in Table 7. Recall that the JM measure is equal to our measure (prior to logarithmic transformation) divided by the market value of the firm and multiplied by $\$ 100,000$. The R-squared for equation (1) is $16.1 \%$, consistent with prior research that uses percentage ownership as a dependent variable. The coefficients have the same signs as the corresponding coefficients in Table 2, with the exception of the coefficient on $\log (\mathrm{MV}$ equity). $\log (\mathrm{MV}$ equity) is now significantly negative, consistent with the findings of Demsetz and Lehn (1985), Bizjak, Brickley, and Coles (1993), and Baker and Hall (1998). In Table 2, we predicted and found a positive coefficient on size which is less than one, consistent with CEO incentives growing as a concave function of firm size.

Table 7 also presents results from a Tobit estimation of equation (2) using the JM incentive measure. Consistent with our hypothesis, we find that the incentive residual remains significantly negatively associated with grants of new incentives. However, consistent with Yermack (1995), and in contrast to our findings in Table 4, the specification in Table 7 yields

results that are inconsistent with economic intuition, in that growth opportunities and stock return exhibit significantly negative associations with grants of incentives. The fact that we are able to replicate Yermack's (1995) findings with a later sample and a more comprehensive measure of equity incentives suggests that Yermack's findings stem from using the JM fractional incentive measure, not from problems with measurement error or power.

\section{Conclusion}

This paper examines whether firms' use of CEO equity incentives and stock-based compensation is consistent with economic determinants and an optimal contracting perspective. 
Building on the hypothesis of Demsetz and Lehn (1985), we make the joint hypothesis that firms set optimal levels of CEO equity incentives and that firms use new grants of equity incentives, such as stock options and restricted stock, to correct deviations from these optimal incentive levels. Our results support these predictions. Firms not only set an optimal level of CEO incentives, but firms actively manage to this level by varying incentive grants.

We find that the hypothesized determinants of equity incentives explain a significant portion of the variation in CEOs' portfolios of equity incentives. We use the residual from an incentive levels model as a proxy for the deviation between the CEO's existing level of incentives and the CEO's optimal incentive level. Consistent with our hypothesis that firms use the grants of new incentives to correct deviations in CEOs' portfolio holdings of incentives, we find that grants of new equity incentives to CEOs are negatively related to this residual. Grants of new equity incentives are also positively associated with variables that proxy for firms' desire to use stock compensation in lieu of cash compensation.

In contrast to the findings of previous researchers (e.g., Yermack, 1995), our overall evidence is consistent with firms effectively using grants of equity incentives, and is consistent with economic theory of optimal contracting. The differences in our findings stem from three innovations in our research methodology. First, our theory and tests distinguish between CEOs' portfolio holdings of equity incentives and new grants of equity incentives. As Yermack (1995) recognizes, a potential problem with his tests and similar tests, such as recent studies by Bryan, Hwang, and Lilien (1998) and Janakiraman (1998), is that predictions that apply to portfolio holdings of equity incentives are tested on a single year incentive grant (which is only the most recently added portion of the CEO's portfolio of incentives). Second, we measure equity incentives as the total incentives provided by stock and stock options, and show that the 
explanatory power for these total incentives is much greater than for stock alone. Previous studies have tended to examine the determinants of levels of stock or option holdings in isolation.

Finally, we proxy for the incentive effects of CEOs' stock and option holdings using the change in the value of stock and option holdings for a $1 \%$ change in the stock price. Previous researchers, such as Demsetz and Lehn (1985), Morck, Shleifer, and Vishny (1988), Jensen and Murphy (1990), and Yermack (1995) use measures related to the fraction of the firm owned by the CEO. These fractional ownership measures are equivalent to our measure of incentives deflated by the market value of the firm. Sensitivity tests using fractional ownership confirm the puzzling results of Yermack (1995), while tests using our measure yield the results predicted by theory. This contrast suggests that the use of fractional equity ownership as a proxy for CEO incentives can produce results that run counter to economic intuition, at least in the case of grants of equity incentives. A fruitful avenue for future research would be to re-examine other counterintuitive findings that have been obtained with fractional ownership measures (e.g., the Morck, Shleifer, and Vishny (1988) and related findings that higher fractional ownership can lead to better firm performance). 


\section{Appendix A: Calculating option portfolio sensitivities}

\section{A.1 Black-Scholes (1973) sensitivities of individual stock options}

Estimates of the sensitivity of a stock option's value to changes in price are calculated based on the Black-Scholes (1973) formula for valuing European call options, as modified to account for dividend payouts by Merton (1973).

$$
\text { Option value }=\left[S \mathrm{e}^{-\mathrm{dT}} \mathrm{N}(\mathrm{Z})-\mathrm{X} \mathrm{e}^{-\mathrm{rT}} \mathrm{N}\left(\mathrm{Z}-\sigma \mathrm{T}^{(1 / 2)}\right)\right],
$$

where

$\mathrm{Z}=\left[\log (\mathrm{S} / \mathrm{X})+\mathrm{T}\left(\mathrm{r}-\mathrm{d}+\sigma^{2} / 2\right)\right] / \sigma \mathrm{T}^{(1 / 2)}$

$\mathrm{N}=\quad$ cumulative probability function for the normal distribution

$\mathrm{S}=$ price of the underlying stock (from CRSP)

$\mathrm{X}=$ exercise price of the option (from Execucomp)

$\sigma=\quad$ expected stock-return volatility over the life of the option (from CRSP - standard deviation of daily stock returns over 120 days prior to sensitivity measurement date)

$r=\quad$ risk-free interest rate (treasury yield corresponding to time-to-maturity)

$\mathrm{T}=$ time-to-maturity of the option in years (from Execucomp)

$\mathrm{d}=\quad$ expected dividend rate over the life of the option (from Compustat - dividends paid in previous four quarters divided by end of period price)

The partial derivative of the Black/Scholes value with respect to stock price is expressed as: $\partial($ option value $) / \partial($ price $)=\mathrm{e}^{-\mathrm{dT}} \mathrm{N}(Z)$.

The sensitivity of stock option value with respect to a $1 \%$ change in stock price is defined as:

Sensitivity of option value to stock price $=\mathrm{e}^{-\mathrm{dT}} \mathrm{N}(Z) *($ price/100). 


\section{A.2 Estimating the sensitivity of stock option portfolios - Core and Guay (1999) method}

1. Obtain data on an executive's option portfolio from the most recent proxy statement:

a. Data on most recent year's grant: (i) number of options, (ii) exercise price, and (iii) timeto-maturity.

b. Data on previously granted options: (i) number of exercisable and unexercisable options outstanding, and (ii) current realizable value of exercisable and unexercisable options. To avoid double counting of the most recent year's grant, the number and realizable value of the unexercisable options is reduced by the number and realizable value of the current year's grant. If the number of options in the most recent year's grant exceeds the number of unexercisable options, the number and realizable value of the exercisable options is reduced by the excess of the number and realizable value of the current year's grant over the number and realizable value of the unexercisable options.

2. Compute the sensitivity of the executive's option portfolio to year-end stock price:

a. Most recent year's grant: compute Black/Scholes sensitivity to year-end stock price - all input parameters are readily available.

b. Previously granted options: (i) Compute average exercise price of exercisable and unexercisable options using current realizable value. The average exercise price is estimated as [year-end price - (realizable value / number of options)]. (ii) Set time-to maturity of unexercisable options equal to one year less than time-to-maturity of most recent year's grant (or nine years if no new grant was made); set time-to maturity of exercisable options equal to three years less than time-to-maturity of unexercisable options (or six years if no new grant was made). (iii) Compute Black/Scholes sensitivity to stock price. All remaining input parameters are readily available. 


\section{Appendix B: Expected grant values and marginal effects in the Heckman and Tobit models}

The Heckman (1979) model consists of a probit model for the option grant decision and a linear regression model for the logarithm of the equity incentives provided by the grant:

$$
O^{*}=x_{1} \beta_{1}+\varepsilon_{1}
$$

$\log ($ New incentive grant +1$)=x_{2} \beta_{2}+\varepsilon_{2}$, if a grant is made and 0 otherwise

The two error terms are assumed to be normally distributed with correlation $\rho$. The error term in the linear regression model of equation (5) has standard deviation $\sigma_{2}$, and the standard deviation of the error term in the probit model of equation (4) is normalized to one.

Under these assumptions, the expected value of the logarithm of the grant's incentives, given that the grant is made, is equal to:

$$
E[\log (\text { New incentive grant }+1) \mid \text { Grant }]=x_{2} \beta_{2}+\left(\rho \sigma_{2}\right) \lambda \text {. }
$$

$\lambda$, the inverse Mills ratio, is a decreasing function of the probability that an option grant is made,

and is equal to: $\quad \lambda=\frac{\phi\left(x_{1} \beta_{1}\right)}{\Phi\left(x_{1} \beta_{1}\right)}$,

where $\beta_{1}$ are the coefficients from the probit model and $\phi(\bullet)$ and $\Phi(\bullet)$ are the density and cumulative density, respectively, of the standard normal. Note that equation (A3) implies that regression estimates of $\beta_{2}$ will suffer from an omitted variables bias if ordinary least squares is used to estimate equation (A2).

When $\mathrm{x}_{1}=\mathrm{x}_{2}$ and $\beta_{1}$ is restricted to equal $\beta_{2}$, the Tobit model results. In this model, the expected value of $\log (\mathrm{New}$ incentive grant +1$)$, given that a grant is made is equal to:

$$
E[\log (\text { New incentive grant }+1) \mid \text { Grant }]=x_{2} \beta_{2}+\sigma_{2} \lambda,
$$


and, $\lambda$, the inverse Mills ratio is equal to: $\lambda=\frac{\phi\left(x_{2} \beta_{2}\right)}{\Phi\left(x_{2} \beta_{2}\right)}$.

Again, equation (A4*) implies that regression estimates of $\beta_{2}$ will suffer from an omitted variables if ordinary least squares is used to estimate equation (A2).

In the Heckman model, the unconditional expected value of the logarithm of incentives provided by the grant is equal to the probability that a grant is made, $\Phi\left(\mathrm{x}_{1} \beta_{1}\right)$, multiplied by equation (A3), plus zero times the probability that no grant is made, $1-\Phi\left(\mathrm{x}_{1} \beta_{1}\right)$ :

$E[\log ($ New incentive grant +1$)]=\Phi\left(x_{1} \beta_{1}\right) x_{2} \beta_{2}+\left(\rho \sigma_{2}\right) \phi\left(x_{1} \beta_{1}\right)$.

If a variable $\mathrm{x}_{\mathrm{j}}$ appears in both the linear model and the probit model, the marginal effect of this variable on the expected value of the grant is equal to sum of the variable's direct effect on the value of the grant and the variable's indirect effect on increasing the probability that a grant is made (Greene, 1997):

$$
\frac{\partial E[\log (\text { New incentive grant }+1)]}{\partial x_{j}}=\Phi\left(x_{1} \beta_{1}\right) \beta_{2 j}+\phi\left(x_{1} \beta_{1}\right) \beta_{1 j}\left(x_{2} \beta_{2}-\left(\rho \sigma_{2} x_{1} \beta_{1}\right)\right),
$$

where $x_{1} \beta_{1}$ and $x_{2} \beta_{2}$ are evaluated at the mean of the regressors for the full sample.

If the Tobit model is used, the unconditional expected value of the logarithm of incentives provided by the grant is equal to:

$$
E[\log (\text { New incentive grant }+1)]=\Phi\left(\frac{x_{2} \beta_{2}}{\sigma_{2}}\right) x_{2} \beta_{2}+\sigma_{2} \phi\left(x_{2} \beta_{2}\right) .
$$

The marginal effect in the Tobit model is equal to:

$$
\frac{\partial E[\log (\text { New incentive grant }+1)]}{\partial x_{j}}=\Phi\left(\frac{x_{2} \beta_{2}}{\sigma_{2}}\right) \beta_{2 j} .
$$




\section{References}

Baber W., S. Janakiraman, and S. Kang, 1996, Investment opportunities and the structure of executive compensation, Journal of Accounting and Economics 21, 297-318.

Baker, G. and B. Hall, 1998, CEO incentives and firm size, NBER Working paper 6868.

Bizjak, J., J. Brickley, and J. Coles, 1993, Stock-based incentive compensation and investment behavior, Journal of Accounting and Economics 16, 349-372.

Black, F. and M. Scholes, 1973, The pricing of options and corporate liabilities, Journal of Political Economy 81, 637-654.

Bryan, S., L. Hwang, and S. Lilien, 1998, CEO stock option awards: An empirical analysis and synthesis of the economic determinants, Working paper, Baruch College, CUNY.

Core, J. and W. Guay, 1999, Estimating the value of stock option portfolios and their sensitivities to price and volatility. Working paper, University of Pennsylvania.

Cuny, C. and P. Jorion, 1995, Valuing executive stock options with a departure decision, Journal of Accounting and Economics 20, 193-205.

Dechow, P., A. Hutton, and R. Sloan, 1996, Economic consequences of accounting for stockbased compensation Journal of Accounting Research 34, 1-20.

Dechow, P. and R. Sloan, 1991, Executive Incentives and the Horizon Problem: An Empirical Investigation. Journal of Accounting \& Economics 14, 51-89.

Demsetz, H. and K. Lehn, 1985, The structure of corporate ownership: causes and consequences. Journal of Political Economy, 1155-1177.

Fama, E. and J. MacBeth, 1973, Risk, return, and equilibrium: Empirical tests, Journal of Political Economy 81, 607-36.

Gaver, J. and K. Gaver, 1993, Additional evidence on the association between the investment opportunity set and corporate financing, dividend, and compensation policies, Journal of Accounting and Economics 16, 125-160.

Gibbons, R. and K. Murphy, 1992, Optimal incentive contracts in the presence of career concerns: Theory and evidence, The Journal of Political Economy 100, 468-505.

Greene, W., 1997. Econometric Analysis. Prentice Hall, Upper Saddle River, NJ.

Guay, W., 1999, The sensitivity of CEO wealth to equity risk: an analysis of the magnitude and determinants, Journal of Financial Economics 53, 43-71. 
Hall, B. and J. Liebman, 1998, Are CEOs really paid like bureaucrats?, The Quarterly Journal of Economics 103, 653-691.

Haubrich, J., 1994, Risk-aversion, performance pay, and the principal-agent problem, Journal of Political Economy 102, 258-276.

Heckman, J., 1979. Sample selection bias as a specification error, Econometrica 47, 153-61.

Holmstrom, B., 1982, Moral hazard in teams, Bell Journal of Economics 13, 324-340.

Himmelberg, C., G. Hubbard, and D. Palia, 1999, Understanding the determinants of managerial ownership and the link between ownership and performance, Journal of Financial Economics 53, 353-384.

Huddart, S., 1994, Employee stock options, Journal of Accounting and Economics 18, 207-231.

Janakiraman, S., 1998, Stock option awards and exercise behavior of CEOs: An empirical analysis, Working paper, University of Texas at Dallas.

Jensen, M., 1986, Agency costs of free cash flow, corporate finance, and takeovers, American Economic Review 76, 323-329.

Jensen, M. and K. Murphy, 1990, Performance pay and top-management incentives, Journal of Political Economy 98, 225-264.

Jensen, M. and W. Meckling, 1976. Theory of the firm: Managerial behavior, agency costs and ownership structure, Journal of Financial Economics 3, 305-360.

Kole, S., 1997, The complexity of compensation contracts, Journal of Financial Economics 43, 79-104.

Lang, L., R. Stulz, and R. Walkling, 1991, A test of the free cash flow hypothesis: The case of bidder returns, Journal of Financial Economics 29, 315-355.

Matsunaga, S., 1995, The effects of financial reporting costs on the use of employee stock options. The Accounting Review 70, 1-26.

Mehran, H., 1995, Executive compensation structure, ownership, and firm performance, Journal of Financial Economics 38, 163-184.

Merton, R., 1973, Theory of rational option pricing, Bell Journal of Economics and Management Science 4, 141-183. 
Milbourn, T., 1998, The executive compensation puzzle: theory and evidence. Working paper, London Business School.

Morck, R., A. Shleifer, and R. Vishny, 1988, Management ownership and market valuation: An empirical analysis. Journal of Financial Economics 20, 293-315.

Murphy, K, 1985, Corporate performance and managerial remuneration: An empirical analysis. Journal of Accounting \& Economics 7, 11-42.

Murphy, K., 1998, Executive compensation, forthcoming, in Ed. O Ashenfelter and D. Card, Handbook of Labor Economics, Vol. 3 (Amsterdam: North-Holland).

Ofek, E. and D. Yermack, 1997, Taking stock: does equity-based compensation increase managers' ownership? Working paper, New York University.

Palia, D., 1998, The endogeneity of managerial compensation in firm valuation: a solution. Working paper, Columbia University.

Smith, C. and R. Watts, 1982, Incentive and tax effects of executive compensation plans, Australian Journal of Management, 139-157.

Smith, C. and R. Watts, 1992, The investment opportunity set and corporate financing, dividends, and compensation policies, Journal of Financial Economics 32, 263-292.

Yermack, D., 1995, Do corporations award CEO stock options effectively?, Journal of Financial Economics 39, 237-269. 
Table 1

Summary statistics for portfolio equity incentives and their determinants

Panel A: Descriptive statistics

\begin{tabular}{|c|c|c|c|c|c|}
\hline Variable & Mean & Std Dev & Q1 & Median & Q3 \\
\hline Portfolio equity incentives $_{\mathrm{t}-1}$ & 557,732 & $3,680,516$ & 45,758 & 117,434 & 331,670 \\
\hline $\log (\text { portfolio equity incentives })_{t-1}$ & 11.68 & 1.64 & 10.73 & 11.67 & 12.71 \\
\hline $\log (\text { market value of equity })_{t-1}$ & 6.87 & 1.45 & 5.77 & 6.73 & 7.88 \\
\hline $\log (\text { idiosyncratic risk })_{\mathrm{t}-1}$ & -1.24 & 0.45 & -1.59 & -1.25 & -0.91 \\
\hline Book-to-market $t_{\text {-1 }}$ & 0.63 & 0.24 & 0.45 & 0.64 & 0.82 \\
\hline $\log (\mathrm{CEO} \text { tenure })_{\mathrm{t}-1}$ & 1.20 & 2.51 & 0.73 & 1.63 & 2.30 \\
\hline Free-cash-flow problem ${ }_{\mathrm{t}-1}$ & $0.21 \%$ & $1.43 \%$ & $0.00 \%$ & $0.00 \%$ & $0.00 \%$ \\
\hline
\end{tabular}

Panel B: Correlation matrix

(correlations with an absolute value greater than 0.03 are significant at a 0.05 level)

\begin{tabular}{|c|c|c|c|c|c|}
\hline $\log (\text { market value of equity })_{t-1}$ & 1.00 & & & & \\
\hline $\log (\text { idiosyncratic risk })_{\mathrm{t}-1}$ & -0.56 & 1.00 & & & \\
\hline Book-to-market $t_{\text {-1 }}$ & -0.23 & -0.14 & 1.00 & & \\
\hline $\log (\mathrm{CEO} \text { tenure })_{\mathrm{t}-1}$ & 0.02 & 0.00 & -0.07 & 1.00 & \\
\hline Free-cash-flow problem ${ }_{\mathrm{t}-1}$ & -0.14 & 0.07 & 0.28 & -0.01 & 1.00 \\
\hline
\end{tabular}

The sample consists of 5,352 CEO-year observations from 1992 to 1996 . Portfolio equity incentives is the sensitivity of the total value of stock and options held by the CEO to a $1 \%$ change in stock price, and is measured at fiscal-year end. $\log$ (market value of equity) is the logarithm of the market value of the firm's equity in millions of dollars. $\log$ (idiosyncratic risk) is the logarithm of the standard deviation of the residual from a market model regression estimated over 36 months of returns ending with the fiscal year-end (subject to a minimum of 12 monthly returns). Book-to-market is (book value of assets) / (book value of liabilities + market value of equity). $\log (\mathrm{CEO}$ tenure) is the logarithm of CEO tenure in years. Free-cash-flow problem is equal to zero if the book-to-market ratio is less than one, and is the three-year average of [(cash flow from operations - common and preferred stock dividends) / total assets], otherwise. All variables are measured at or for the fiscal year-end corresponding to the year end when portfolio equity incentives are measured. 
Table 2

Determinants of the logarithm of (portfolio equity incentives) $\mathrm{t}-1$

\begin{tabular}{|c|c|c|c|}
\hline $\begin{array}{c}\text { Independent } \\
\text { variable } \\
\end{array}$ & $\begin{array}{c}\text { Predicted } \\
\text { sign } \\
\end{array}$ & $\begin{array}{c}\text { Option and stock } \\
\text { incentives }\end{array}$ & Stock incentives only \\
\hline $\log (\mathrm{MV} \text { equity })_{\mathrm{t}-1}$ & + & $\begin{array}{c}0.55 \\
(36.49)\end{array}$ & $\begin{array}{c}0.39 \\
(16.50)\end{array}$ \\
\hline $\log (\text { idiosyncratic risk })_{\mathrm{t}-1}$ & + & $\begin{array}{c}0.84 \\
(15.99)\end{array}$ & $\begin{array}{c}0.51 \\
(6.12)\end{array}$ \\
\hline Book-to-market $t_{t-1}$ & - & $\begin{array}{c}-1.79 \\
(-21.47)\end{array}$ & $\begin{array}{c}-2.59 \\
(-19.61)\end{array}$ \\
\hline $\log (\mathrm{CEO} \text { tenure })_{\mathrm{t}-1}$ & + & $\begin{array}{c}0.14 \\
(20.92)\end{array}$ & $\begin{array}{c}0.21 \\
(20.37)\end{array}$ \\
\hline Free-cash-flow problem ${ }_{t-1}$ & + & $\begin{array}{c}1.21 \\
(1.01)\end{array}$ & $\begin{array}{c}2.29 \\
(1.17)\end{array}$ \\
\hline $\mathrm{N}$ & & 5,352 & 5,249 \\
\hline Adjusted $\mathrm{R}^{2}$ & & $47.8 \%$ & $28.7 \%$ \\
\hline
\end{tabular}

The sample consists of 5,352 CEO-year observations from 1992 to 1996. T-statistics (in parentheses) are based on OLS standard errors. Stock and option incentives (the dependent variable in Column 1) is the logarithm of the sensitivity of the total value of stock and options held by the CEO to a $1 \%$ change in stock price. Stock incentives only (Column 2) is the logarithm of the sensitivity of the value of the stock held by the CEO to a $1 \%$ change in stock price. Both variables are measured at fiscal year-end. All other variables are defined in Table 1. Coefficients on 19 industry indicator variables and 4 year indicator variables not shown. 
Table 3

Descriptive statistics for grants of new equity incentives and their determinants

Panel A: Descriptive statistics

\begin{tabular}{|c|c|c|c|c|c|}
\hline Variable & Mean & Std Dev & Q1 & Median & Q3 \\
\hline Grant $_{\mathrm{t}}$ (indicator variable) & 0.74 & 0.44 & 0.00 & 1.00 & 1.00 \\
\hline New equity incentives $_{t}(\mathrm{~N}=3,282)$ & 32,307 & 103,949 & 4,908 & 12,251 & 27,741 \\
\hline $\log (\text { New equity incentives }+1)_{t}$ & 9.37 & 1.39 & 8.50 & 9.41 & 10.23 \\
\hline Incentive residual $_{\mathrm{t}-1}$ & 0.02 & 1.16 & -0.72 & -0.08 & 0.69 \\
\hline $\log (\text { sales })_{t-1}$ & 6.81 & 1.61 & 5.79 & 6.80 & 7.93 \\
\hline Book-to-market $_{\mathrm{t}-1}$ & 0.63 & 0.24 & 0.44 & 0.64 & 0.82 \\
\hline Net operating $\operatorname{loss}_{\mathrm{t}-1}$ & 0.25 & 0.43 & 0.00 & 0.00 & 0.00 \\
\hline Cash flow shortfall ${ }_{t-1}$ & $2.49 \%$ & $8.63 \%$ & $-2.21 \%$ & $-0.99 \%$ & $5.30 \%$ \\
\hline Dividend constraint $_{\mathrm{t}-1}$ & 0.44 & 0.50 & 0.00 & 0.00 & 1.00 \\
\hline Stock return $_{t}$ & $18.35 \%$ & $42.28 \%$ & $-6.84 \%$ & $13.30 \%$ & $35.85 \%$ \\
\hline Stock return $_{\mathrm{t}-1}$ & $19.72 \%$ & $45.17 \%$ & $-6.13 \%$ & $13.23 \%$ & $35.11 \%$ \\
\hline
\end{tabular}

Panel B: Correlation matrix

(correlations with an absolute value greater than 0.03 are significant at a 0.05 level)

\begin{tabular}{|c|c|c|c|c|c|c|c|c|}
\hline Incentive residual $_{\mathrm{t}-1}$ & 1.00 & & & & & & & \\
\hline $\log (\text { sales })_{t-1}$ & 0.01 & 1.00 & & & & & & \\
\hline Book-to-market ${ }_{\mathrm{t}-1}$ & -0.00 & 0.24 & 1.00 & & & & & \\
\hline Net operating $\operatorname{loss}_{\mathrm{t}-1}$ & -0.02 & -0.15 & -0.05 & 1.00 & & & & \\
\hline Cash flow shortfall t-1 & 0.01 & -0.38 & -0.06 & 0.14 & 1.00 & & & \\
\hline Dividend constraint $_{t-1}$ & 0.05 & -0.40 & -0.16 & 0.23 & 0.26 & 1.00 & & \\
\hline Stock return $_{\mathrm{t}}$ & 0.03 & -0.03 & 0.03 & 0.04 & -0.06 & 0.06 & 1.00 & \\
\hline Stock return $_{\mathrm{t}-1}$ & 0.02 & -0.08 & -0.37 & 0.05 & -0.05 & 0.11 & 0.00 & 1.00 \\
\hline
\end{tabular}

The sample consists of 4,431 CEO-year observations from 1993 to 1997, in which incentive grants are made in 3,282 CEO-years. New equity incentives is the sum of the sensitivities of grants of stock options and restricted stock made during the fiscal year to a $1 \%$ change in stock price. The incentive residual is the residual from a regression of the incentives from stock options and stockholdings on their determinants as estimated in Table 2. This residual is estimated at the end of the fiscal year prior to the fiscal year in which the grant of new equity incentives is awarded. Stock return ${ }_{t}$ is the percentage return on the firm's stock in the fiscal year in which incentives are awarded. All other variables are measured at or for the fiscal year end prior to which the grant is made. Book-to-market is (book value of assets) / (book value of liabilities + market value of equity). Net operating loss is an indicator variable equal to one if the firm has net operating loss carry-forwards in any of the three years prior to the year the new equity grant is awarded. Cash flow shortfall is the three-year average of [(common and preferred dividends + cash flow from investing - cash flow from operations)/total assets]. Dividend constraint is an indicator equal to one if the firm is dividend constrained in any of the three years prior to the year the new equity grant is awarded. We categorize a firm as dividend constrained if [(retained earnings at year-end + cash dividends and stock repurchases during the year)/the prior year's cash dividends and stock repurchases], is less than two. If the denominator is zero for all three years, we also categorize the firm as dividend constrained. 
Table 4

Tobit estimation of the determinants of the annual grant of equity incentives

\begin{tabular}{|c|c|c|c|c|c|}
\hline \multirow[b]{2}{*}{$\begin{array}{c}\text { Independent } \\
\text { variable }\end{array}$} & \multirow[b]{2}{*}{$\begin{array}{l}\text { Predicted } \\
\text { sign }\end{array}$} & \multicolumn{2}{|c|}{ (1) } & \multicolumn{2}{|c|}{ (2) } \\
\hline & & Estimate & Marginal & Estimate & Marginal \\
\hline Incentive residual $_{\mathrm{t}-1}$ & - & $\begin{array}{c}-0.54 \\
(-7.20)\end{array}$ & -0.47 & $\begin{array}{c}-0.56 \\
(-7.81)\end{array}$ & -0.49 \\
\hline $\log (\text { sales })_{\mathrm{t}-1}$ & + & & & $\begin{array}{c}0.96 \\
(15.18)\end{array}$ & 0.84 \\
\hline Book-to-market ${ }_{\mathrm{t}-1}$ & - & & & $\begin{array}{c}-1.24 \\
(-2.92)\end{array}$ & -1.09 \\
\hline Net operating $\operatorname{loss}_{\mathrm{t}-1}$ & + & & & $\begin{array}{c}0.08 \\
(0.40)\end{array}$ & 0.07 \\
\hline Cash flow shortfall ${ }_{t-1}$ & + & & & $\begin{array}{c}3.02 \\
(2.77)\end{array}$ & 2.66 \\
\hline Dividend constraint $_{\mathrm{t}-1}$ & + & & & $\begin{array}{c}0.43 \\
(2.23)\end{array}$ & 0.38 \\
\hline Stock return $_{\mathrm{t}}$ & + & & & $\begin{array}{c}0.68 \\
(3.36)\end{array}$ & 0.60 \\
\hline Stock return $_{\mathrm{t}-1}$ & + & & & $\begin{array}{c}0.13 \\
(0.64)\end{array}$ & 0.12 \\
\hline $\begin{array}{l}\text { Likelihood ratio test for the } \\
\text { restriction that the slopes of all the } \\
\text { control variables are equal to } 0\end{array}$ & & & & 370.1 & \\
\hline p-value & & & & $<0.001$ & \\
\hline $\begin{array}{l}\mathrm{N} \\
\text { Number of grants }\end{array}$ & & $\begin{array}{l}4,431 \\
3,283\end{array}$ & & $\begin{array}{l}4,431 \\
3,283\end{array}$ & \\
\hline
\end{tabular}

The sample consists of 4,431 CEO-year observations from 1993 to 1997. T-statistics (in parentheses) are based on maximum likelihood standard errors. The dependent variable is logarithm (New incentive grant +1 ). The Tobit estimation procedure jointly estimates the probability of a grant and the size of a grant for the grant observations and non-grant observations. All variables are defined in Table 3. Coefficients on 19 industry indicator variables and 4 year indicator variables are not shown. 
Table 5

Heckman two-stage estimation of the determinants of the annual grant of equity incentives

\begin{tabular}{|c|c|c|c|c|}
\hline $\begin{array}{c}\text { Independent } \\
\text { variable }\end{array}$ & $\begin{array}{l}\text { Predicted } \\
\text { sign }\end{array}$ & Probit & OLS & Marginal \\
\hline Incentive residual $_{t-1}$ & - & $\begin{array}{l}-0.16 \\
(-9.07)\end{array}$ & $\begin{array}{c}-0.01 \\
(-0.02)\end{array}$ & -0.33 \\
\hline $\log (\text { sales })_{t-1}$ & + & $\begin{array}{c}0.16 \\
(9.57)\end{array}$ & $\begin{array}{c}0.65 \\
(8.02)\end{array}$ & 0.82 \\
\hline Book-to-market $t_{t-1}$ & - & $\begin{array}{c}-0.09 \\
(-0.85)\end{array}$ & $\begin{array}{l}-1.56 \\
(-8.50)\end{array}$ & -1.36 \\
\hline Net operating $\operatorname{loss}_{\mathrm{t}-1}$ & + & $\begin{array}{c}0.01 \\
(0.23)\end{array}$ & $\begin{array}{c}0.05 \\
(0.54)\end{array}$ & 0.06 \\
\hline Cash flow shortfall $\mathrm{t}_{\mathrm{t}-1}$ & + & $\begin{array}{c}0.42 \\
(1.57)\end{array}$ & $\begin{array}{c}2.27 \\
(4.47)\end{array}$ & 2.59 \\
\hline Dividend constraint $_{\mathrm{t}-1}$ & + & $\begin{array}{c}0.02 \\
(0.34)\end{array}$ & $\begin{array}{c}0.46 \\
(5.71)\end{array}$ & 0.38 \\
\hline Stock return $_{\mathrm{t}}$ & + & $\begin{array}{c}0.11 \\
(2.12)\end{array}$ & $\begin{array}{c}0.45 \\
(4.47)\end{array}$ & 0.56 \\
\hline Stock return $_{\mathrm{t}-1}$ & + & $\begin{array}{c}0.01 \\
(0.15)\end{array}$ & $\begin{array}{c}0.11 \\
(1.28)\end{array}$ & 0.10 \\
\hline Inverse Mills ratio & & & $\begin{array}{l}2.45 \\
(2.19)\end{array}$ & \\
\hline $\begin{array}{l}\text { Pseudo } \mathrm{R}^{2} \\
\text { Adjusted } \mathrm{R}^{2} \\
\mathrm{~N}\end{array}$ & & 4,431 & $\begin{array}{c}35.5 \% \\
3,283\end{array}$ & \\
\hline
\end{tabular}

The sample consists of 4,431 CEO-year observations from 1993 to 1997. T-statistics (in parentheses) are based on maximum likelihood standard errors for the probit model and Heckman (1979) standard errors for the OLS regression. The Heckman procedure consists of a first-stage probit estimation of the probability of a grant, and a second-stage OLS estimation of the size of a grant for the grant observations only. The dependent variable is logarithm (New incentive grant +1$)$. The inverse Mills ratio reflects the fact that the grant observations are predictable. All variables are defined in Table 3. Coefficients on 4 year indicator variables not shown in Panel 1. Coefficients on 19 industry indicator variables and 4 year indicator variables not shown in Panel 2. 
Table 6

Sensitivity analysis using firm-effects (FE) incentive residual

\begin{tabular}{|c|c|c|c|}
\hline \multicolumn{2}{|c|}{ Portfolio incentives model } & \multicolumn{2}{|c|}{ Grant model } \\
\hline $\begin{array}{c}\text { Independent } \\
\text { Variable }\end{array}$ & $\begin{array}{c}\text { FE } \\
\text { estimates of } \\
\text { portfolio } \\
\text { incentives } \\
\end{array}$ & $\begin{array}{c}\text { Independent } \\
\text { variable }\end{array}$ & $\begin{array}{c}\text { Tobit } \\
\text { estimates of } \\
\text { incentive grant }\end{array}$ \\
\hline $\log (\mathrm{MV} \text { equity })_{\mathrm{t}-1}$ & $\begin{array}{c}0.71 \\
(22.04)\end{array}$ & FE Incentive residual ${ }_{t-1}$ & $\begin{array}{c}-0.59 \\
(-2.60)\end{array}$ \\
\hline $\log (\text { idiosyncratic risk })_{t-1}$ & $\begin{array}{c}0.09 \\
(1.58)\end{array}$ & $\log (\text { sales })_{\mathrm{t}-1}$ & $\begin{array}{c}0.96 \\
(13.33)\end{array}$ \\
\hline Book-to-market $t_{\mathrm{t}-1}$ & $\begin{array}{c}-1.26 \\
(-11.99)\end{array}$ & Book-to-market $t_{\mathrm{t}-1}$ & $\begin{array}{c}-1.15 \\
(-2.33)\end{array}$ \\
\hline $\log (\mathrm{CEO} \text { tenure })_{\mathrm{t}-1}$ & $\begin{array}{c}0.06 \\
(16.64)\end{array}$ & Net operating $\operatorname{loss}_{\mathrm{t}-1}$ & $\begin{array}{c}0.08 \\
(0.33)\end{array}$ \\
\hline \multirow[t]{4}{*}{ Free-cash-flow problem ${ }_{\mathrm{t}-1}$} & $\begin{array}{c}-0.32 \\
(-0.43)\end{array}$ & Cash flow shortfall ${ }_{t-1}$ & $\begin{array}{c}2.50 \\
(1.90)\end{array}$ \\
\hline & & Dividend constraint $_{t-1}$ & $\begin{array}{c}0.47 \\
(2.14)\end{array}$ \\
\hline & & Stock return $_{\mathrm{t}}$ & $\begin{array}{c}0.69 \\
(2.94)\end{array}$ \\
\hline & & Stock return $_{\mathrm{t}-1}$ & $\begin{array}{c}0.47 \\
(1.89)\end{array}$ \\
\hline $\mathrm{N}$ & 5,268 & & 3,237 \\
\hline Adjusted $\mathrm{R}^{2}$ & $89.7 \%$ & & \\
\hline
\end{tabular}

The sample for the estimates of portfolio incentives model reported consists of 5,268 CEO-year observations from 1992 to 1996. We use this specification to estimate firm-effects incentive residuals for 1996, which we use as an explanatory variable for 1997 incentive grants. The results from specifications that generate residuals for 1993, 1994, and 1995 are not tabulated. All variables for this model are defined in Table 1. The firm-effects estimator estimates a separate intercept for each firm. The sample for the Tobit estimates of incentive grants consists of 3,237 CEO-year observations from 1994 to 1997, in which grants are made in 2,430 CEO-years. The firm-effects (FE) incentive residual is computed using all firm-year observations prior to the year in which the grant is made. The remaining variables for this model are defined in Table 3. Coefficients on 19 industry indicator variables and 3 year indicator variables are not shown. 
Table 7

Sensitivity analysis using Jensen and Murphy (1990) incentive measure

\begin{tabular}{|c|c|c|c|}
\hline \multicolumn{2}{|c|}{ Portfolio incentives model } & \multicolumn{2}{|c|}{ Grant model } \\
\hline $\begin{array}{l}\text { Independent } \\
\text { variable }\end{array}$ & $\begin{array}{c}\text { OLS } \\
\text { Estimates of } \\
\text { Portfolio } \\
\text { Incentives } \\
\end{array}$ & $\begin{array}{l}\text { Independent } \\
\text { variable }\end{array}$ & $\begin{array}{c}\text { Tobit } \\
\text { estimates of } \\
\text { incentive grant }\end{array}$ \\
\hline $\log (\mathrm{MV} \text { equity })_{\mathrm{t}-1}$ & $\begin{array}{c}-0.12 \\
(-14.13)\end{array}$ & Incentive residual $_{\mathrm{t}-1}$ & $\begin{array}{c}-0.04 \\
(-4.66)\end{array}$ \\
\hline Idiosyncratic risk $\mathrm{t}_{\mathrm{t}-1}$ & $\begin{array}{c}0.20 \\
(6.69)\end{array}$ & $\log (\text { sales })_{\mathrm{t}-1}$ & $\begin{array}{c}-0.03 \\
(-4.82)\end{array}$ \\
\hline Book-to-market $t_{t-1}$ & $\begin{array}{c}-0.60 \\
(-12.81)\end{array}$ & Book-to-market ${ }_{\mathrm{t}-1}$ & $\begin{array}{c}0.18 \\
(4.23)\end{array}$ \\
\hline $\log (\mathrm{CEO} \text { tenure })_{\mathrm{t}-1}$ & $\begin{array}{c}0.04 \\
(11.36)\end{array}$ & Net operating $\operatorname{loss}_{\mathrm{t}-1}$ & $\begin{array}{c}-0.00 \\
(-0.09)\end{array}$ \\
\hline \multirow[t]{4}{*}{ Free-cash-flow problem ${ }_{t-1}$} & $\begin{array}{c}0.60 \\
(0.89)\end{array}$ & Cash flow shortfall $t_{t-1}$ & $\begin{array}{c}0.35 \\
(3.26)\end{array}$ \\
\hline & & Dividend constraint $_{\mathrm{t}-1}$ & $\begin{array}{c}0.12 \\
(6.48)\end{array}$ \\
\hline & & Stock return $_{t}$ & $\begin{array}{c}-0.10 \\
(-4.88)\end{array}$ \\
\hline & & Stock return $_{\mathrm{t}-1}$ & $\begin{array}{c}0.01 \\
(0.40)\end{array}$ \\
\hline $\mathrm{N}$ & 5,352 & & 4,431 \\
\hline Adjusted $\mathrm{R}^{2}$ & $16.1 \%$ & & \\
\hline
\end{tabular}

T-statistics (in parentheses) are based on OLS standard errors for the first column and based on maximum likelihood standard errors for the Tobit model in the second column. The Jensen and Murphy (1990) incentive measure is [(stock owned / shares outstanding) + (options owned / shares outstanding)*(per option delta)]* \$1000. This variable measures the change in the CEO's wealth for a $\$ 1000$ change in the value of the firm. The sample for the estimates of portfolio incentives consists of 5,352 CEO-year observations from 1992 to 1996. The independent variables for this model are defined in Table 1. The sample for the Tobit estimates of incentive grants consists of 4,431 CEO-year observations from 1993 to 1997, in which grants are made in 3,282 CEO-years. The incentive residual in the grant model is computed using the portfolio incentives model shown. The remaining independent variables for this model are defined in Table 3. Coefficients on 19 industry indicator variables and 4 year indicator variables are not shown. 